Portland State University

PDXScholar

7-24-1987

\title{
The Effect of Body Temperature on Arteriovenous Oxygen Difference During Rest and Activity in the Toad, Bufo Marinus
}

Wayne Bryant Palioca

Portland State University

Follow this and additional works at: https://pdxscholar.library.pdx.edu/open_access_etds

Part of the Biology Commons, and the Physiology Commons

Let us know how access to this document benefits you.

\section{Recommended Citation}

Palioca, Wayne Bryant, "The Effect of Body Temperature on Arteriovenous Oxygen Difference During Rest and Activity in the Toad, Bufo Marinus" (1987). Dissertations and Theses. Paper 3729.

https://doi.org/10.15760/etd.5613

This Thesis is brought to you for free and open access. It has been accepted for inclusion in Dissertations and Theses by an authorized administrator of PDXScholar. Please contact us if we can make this document more accessible: pdxscholar@pdx.edu. 
AN ABSTRACT OF THE THESIS OF Wayne Bryant Palioca for the Master of Science in Biology presented July 24, 1987.

Title: The Effect of Body Temperature on Arteriovenous Oxygen Difference During Rest and Activity in the Toad, Bufo marinus.

APPROVED BY MEMBERS OF THE THESIS COMMITTE:

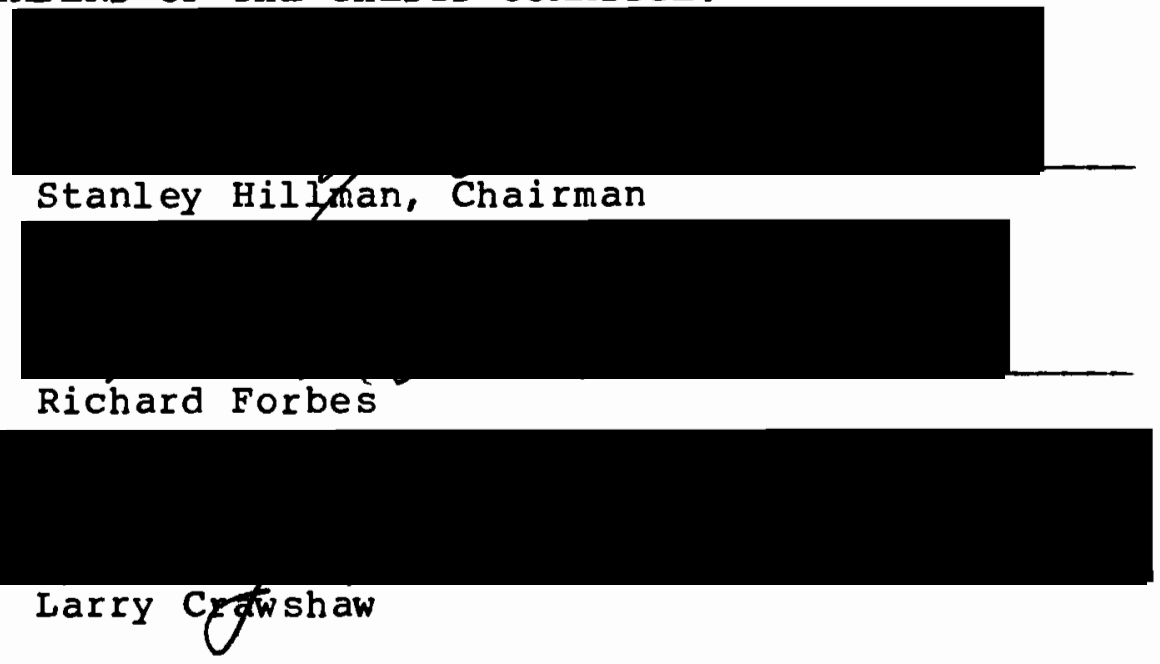

The relative contribution of arteriovenous oxygen (A-V 02) difference to thermally-induced and activity-induced changes in metabolic rate (ن்2) were delineated in the toad, B. marinus. In conjunction, the influence of rest and activity, temperature, and removal of the pericardial sac on separation efficiency (Es) in the anuran ventricle was determined by direct measurement of arterial and venous percent oxygen saturation ( $s$ saturation), using a microsampling technique. 
The site of blood sampling was not critical in the determination of hemoglobin concentration. In contrast, activity status and, secondarily, body temperature significantly influenced hemoglobin concentration. Enforced activity caused a 1.4- to 1.9-fold increase in blood hemoglobin concentration.

Body temperature influenced neither the arterial 8 saturation of resting toads nor venous \& saturation of active toads. However, animals at $10^{\circ} \mathrm{C}$ showed elevated venous $\&$ saturation compared to toads at $2 \theta^{\circ}$ and $3 \theta^{\circ} \mathrm{C}$. Arterial 8 saturation was decreased in active toads at $30^{\circ} \mathrm{C}$. Venous $\&$ saturation dropped to similar levels in active toads at all three temperatures.

The contribution of $A-V$ O2 difference to thermallyinduced changes in $\dot{V} 02$ remained constant in resting $B$. marinus, whereas oxygen extraction was important in augmenting activity-induced changes in $\dot{\mathrm{V}} 2$ in animals at all three temperatures.

The elimination of cutaneous respiration resulted in a 128 reduction in venous 8 saturation, which was reflected in an increase in the $A-V O 2$ difference.

Low body temperature had an adverse effect on Es $(-58)$ in resting toads. Es was high in resting animals at $20^{\circ}$ and $30^{\circ} \mathrm{C}(608$ and 458 respectively). Es during activity was 858,798 , and 458 at $10^{\circ}, 20^{\circ}$, and $30^{\circ} \mathrm{C}$, respectively. 
Removal of the pericardial sac had no effect on arterial and venous saturation or on $\mathrm{A}-\mathrm{V} 02$ difference in active animals at $20^{\circ} \mathrm{C}$. Separation efficiency was also unchanged by this procedure. 
THE EFFECT OF BODY TEMPERATURE ON ARTERIOVENOUS OXYGEN DIFFERENCE DURING REST AND ACTIVITY IN THE TOAD, Bufo marinus

by

WAYNE BRYANT PAL IOCA

A thesis submitted in partial fulfillment of the requirements for the degree of

MASTER OF SCIENCE

in

B IOL OGY

Portland State University

1987 
TO THE OFFICE OF GRADUATE STUDIES AND RESEARCH:

The members of the Committee approve the thesis of Wayne Bryant Palioca presented July 24, 1987 .

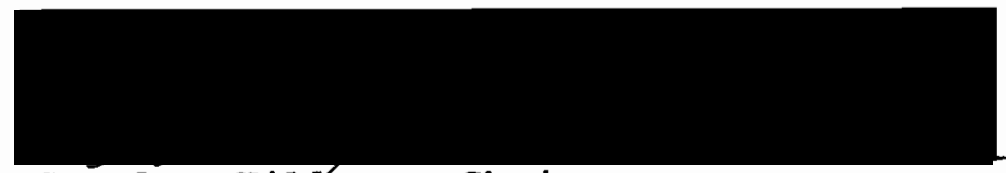

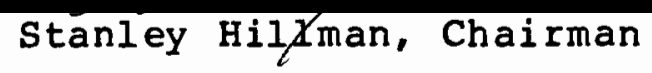

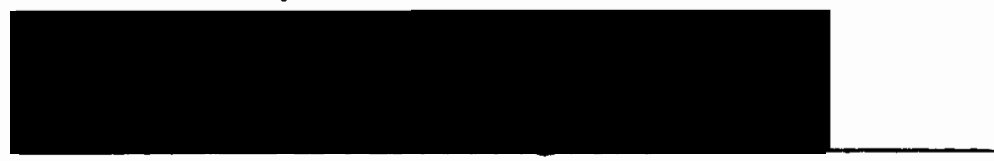

Richard Forbes

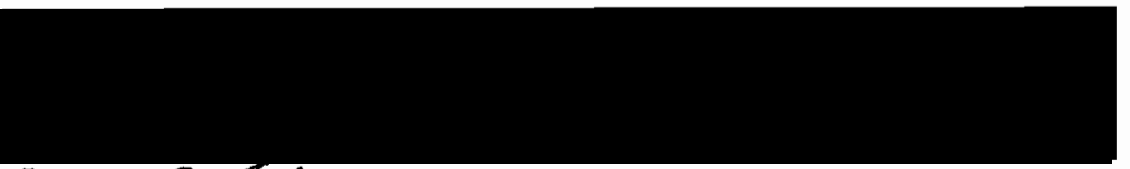

Larry Crgashaw

APPROVED:

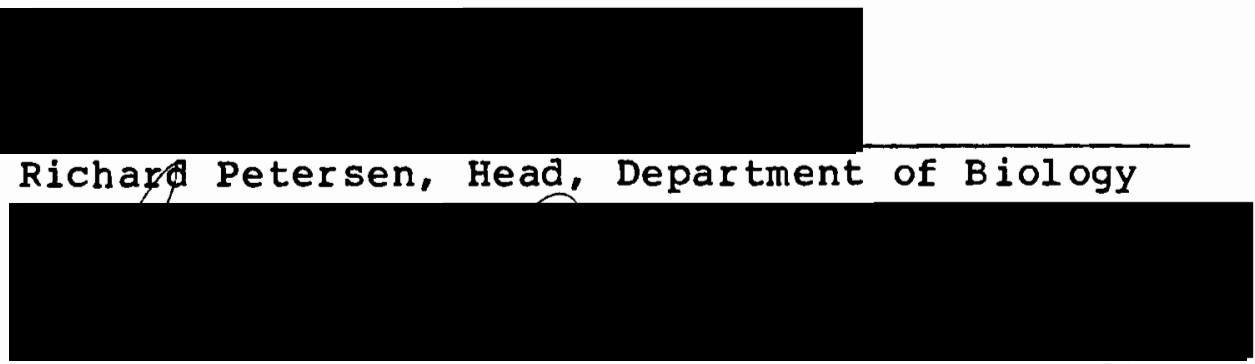

Bernard Ross, Vice Provost for Graduate Studies 


\section{ACRNOWLEDGEMENTS}

The author is grateful to all who gave time, moral and financial support and constructive criticism throughout my collegiate experience. With special thanks to:

My mentor and friend, Stan, whose tutelage led me to Fog's and who introduced me to Frogs. I will always be indebted to him for his guidance, patience and support.

Those faculty, Richard Forbes, Phil Withers and Milan Svoboda, for their encouragement.

My Komrades--Ranger Rick, The Lab Rat, Cardinal, Ralph (Hayteas) Miller, Snapper, Commodore Kimmel, Mark, Lou and Rob--for their companionship and good times!

My siblings, some biological others sociological.

My Mom and Dad, whose love and unwavering support, emotionally and financially, made this endeavor possible. 
TABLE OF CONTENTS

PAGE

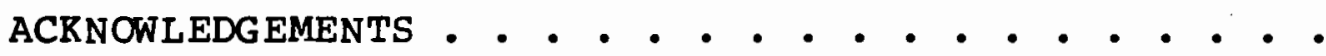

LIST OF TABLES . . . . . . . . . . . . .

vi

LIST OF FIGURES • • . . . . . . . . • • . . •

CHAPTER

I INTRODUCTION . . . . . . . . . . . • . I I

II MATERIALS AND METHODS . . . . . . . 7

Animals . . . . . . . . . . . 7

Surgical Procedure . . . . . . . . 7

Effect of Temperature on $\mathrm{A}-\mathrm{V} \mathrm{O} 2$

Difference • • • • . • • . . 8

Cutaneous Contribution to Blood

Oxygen Saturation . . . . . . . . 9

Effect of Pericardial Sac Removal

on $\mathrm{A}-\mathrm{V}$ O2 Difference . . . . . . . I

Hemoglobin Assay . . . . . . . . . I

Blood Oxygen Content . . . . . . . Il

Calculations . . . . . . . . . 12

Statistics . . . . . . . . . 13

III RESULTS . . . . . . . . . . . . . 14

Hemoglobin Concentration, \& Saturation

and $\mathrm{A}-\mathrm{V}$ O2 Difference...... 
Cutaneous Contribution to Blood

$$
\text { Oxygen Saturation . . . . . . . } 19
$$

Effect of Pericardial Sac Removal

$$
\text { on A-V } 02 \text { Difference... . . . . } 22
$$

Separation Efficiency ........ . 22

IV DISCUSSION . . . . . . . . . . . 29

REFERENCES CITED . . . . . . . . . . . . . 


\section{LIST OF TABLES}

TABLE

PAGE

I Effect of Body Temperature on Blood

Hemoglobin Concentration and Saturation

Parameters in Resting and Active Bufo

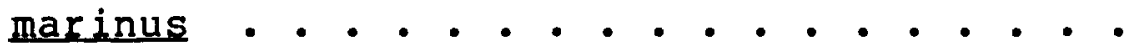

I Effect of Ambient Air and Nitrogen

Environments on Blood Hemoglobin

Concentration and Saturation Parameters

in Active Bufo marinus . . . . . . . .

II Effect of Pericardial Sac Removal on Hemoglobin Concentration and Saturation

Parameters in Active Bufo marinus . . . . 


\section{LIST OF FIGURES}

FIGURE

PAGE

1. Arterial (Art.) and Venous (Ven.) Blood

Hemoglobin Concentration (g $\mathrm{Hb} / \mathrm{l \emptyset \emptyset} \mathrm{ml}$ )

During Rest (R) and Activity (A) at Different

Body Temperatures in B. marinus . . . . . . 16

2. Arterial (Art.) and Venous (Ven.) Blood

Hemoglobin Saturation ( 8 saturation) During

Rest (R) and Activity (A) at Different Body

Temperatures in B. marinus . . . . . . . . 18

3. Arteriovenous 02 Difference During Rest (R)

and Activity (A) at Different Body

Temperatures in $\underline{B}$ marinus . . . . . . . .

4. Blood Hemoglobin Saturation ( $\&$ saturation) and Arteriovenous 02 Difference in Active $\underline{B}$. marinus Exposed to Ambient Air (Amb.) and Nitrogen (Nit.) Environments at $20^{\circ} \mathrm{C} . . . \cdot$. 
5. Blood Hemoglobin Saturation (z saturation) and Arteriovenous 02 Difference in Active B. marinus with Intact (W/PC) and surgically Removed Pericardium (W/O PC) at $20^{\circ} \mathrm{C} . .$.

6. Separation Efficiency (Es) as a Function of Temperature $\left({ }^{\circ} \mathrm{C}\right)$ in Resting and Active $\underline{B}$. marinus . . . . . - . . . . . . . . .

7. Effect of Intact (W/PC) and Pericardial Sac Removal (W/O PC) on Separation Efficiency (Es) in Active B. marinus at $20^{\circ} \mathrm{C} . . . \cdot . \cdot . \cdot$. 


\section{CHAPTER I}

\section{INTRODUCTION}

The anuran cardiovascular system has received considerable attention concerning its ability to separate deoxygenated from oxygenated blood. The anuran heart has septate atria, an aseptate ventricle and a partially divided bulbus cordis (de Graaf, 1957). Distinct schools of thought exist concerning the separation efficiency of such a configuration. Foxon and Walls (1947) argued that it permits random mixing of oxygenated and deoxygenated blood in the ventricle. In contrast, Tazawa et al. (1979) presented evidence favoring a highly selective separation of oxygenated from deoxygenated blood.

The classical hypothesis, as reviewed by Foxon (1955), maintains that a highly selective distribution of blood is achieved by: (1) the trabecular nature of the ventricular wall, which prevents admixture of blood from the two atria during ventricular diastole; (2) shifting of the spiral valve to direct the flow of deoxygenated blood to the pulmocutaneous arch during the initial phase of ventricular systole and to shunt oxygenated blood to the systemic and carotid arches in the final phase of ventricular contraction, and; (3) concomitant changes in resistance of 
the three arches during the cardiac cycle to direct blood flow selectively.

This hypothesis has generated considerable debate. A trans-illumination study of the heart and arterial trunk of Bufo bufo and Rana temporaria (Foxon, 1947) indicated neither directional movements of the spiral valve, nor any differences in time of the movement of blood in the three arches. Radiographic studies reveal considerable mixing in the ventricle (Foxon and Walls, 1947; Foxon, 1951) and a non-selective distribution of blood in the three arches of the frog and toad (Foxon, 1951). A fluoresceincinematographic method employed by de Graaf (1957) demonstrated that in Xenopus laevis the output of the right atrium is not shunted to the left side of the ventricle in any appreciable quantity, but an abundant proportion of the left atrial output is shunted to the right side of the ventricle. More recent work using radiolabeled microspheres (Meyers et al. 1979) has demonstrated the selective shunting of right atrial blood to the systemic and carotid arches in Rana catesbeiana during diving. During air breathing, however, bullfrogs exhibited extreme mixing of atrial outputs in the ventricle.

The anatomical potential for mixing of systemic and pulmocutaneous blood flows in the undivided ventricle is clear (de Graaf, 1957). However, oxygen sampling (Johansen, 1963; Johansen and Ditadi, 1966; Tázawa et al., 1979; 
Withers et al., 1987) and radiopaque contrast (Johansen, 1963) have revealed the ability of an aseptate ventricle to distribute systemic and pulmocutaneous blood selectively. The oxygen saturation of various blood vessels has been determined in Bufo paracnemis (Johansen and Ditadi, 1966 ) and $\underline{R}$. catesbeiana (Tazawa et all., 1979) using open chest point microsampling techniques of the central vascular system. Oxygen saturation of blood in the carotid arch of B. paracnemis was 94.38 , while blood in the sinus venosus was only 14.08 saturated. Sampling from the same blood vessels in $\underline{R}$. Catesbeiana showed a lower degree of separation, though carotid arch saturation remained elevated. Based on the high saturation values observed in the carotid arch and low saturation of the systemic venous return, a high degree of ventricular separation efficiency must exist. This selective shunting of atrial outputs was disrupted when the pericardium was incised in the pithed bullfrog (Tazawa et al., 1979), suggesting that distention of the ventricle decreases separation efficiency. Although cardiac output from the ventricle was estimated to be distributed approximately equally between the pulmocutaneous and systemic arterial vascular beds (Tazawa et al., 1979), elevated pulmonary arterial saturation (75.6\%) observed in B. paracnemis (Johansen and Ditadi, 1966) may be due to shunting of left atrial blood to the pulmocutaneous circuit (de Graaf, 1957). Blood oxygen analysis, radiological 
techniques and intravascular pressure measurements show selective passage of blood from the right and left atria through the ventricle to the pulmonary and systemic arteries, respectively, in Amphiuma tridactylum (Johansen, 1963). The trabecular nature of the ventricle, fluid dynamics and blood pressure changes were all determined to be important factors in the selective distribution of blood in this species.

Currently, only one study (Withers et al., 1987) has addressed the effect of enforced activity on ventricular separation efficiency in the anuran heart. Using arterial and venous $\mathrm{PO} 2$ and $\mathrm{pH}$ measurements, a hemoglobin loading curve (Hall, 1966) linearized by a Hill plot, and empirical calculations (see Tazawa et al., 1979), minimum ventricular separation efficiency was estimated to be $83 \%$ in active $\underline{B}$. marinus at $22^{\circ} \mathrm{C}$.

Increased rates of oxygen comsumption (ن்2) with enforced activity are accomplished by increases in cardiac output (heart rate $\mathrm{X}$ stroke volume) and the arteriovenous oxygen ( $A-V$ O2) difference. Withers et al. (1987) calculated the relative contribution of heart rate (188) and stroke volume $(-28)$ to increases in vo2 with enforced activity. Similar results were obtained by Hedrick (1985) in his investigation of the effects of body temperature and activity on heart rate and pulse volume. In that study, pulse volume through the systemic arch in $\underline{B}$. marinus 
remained nearly constant over a wide range of hearts rates (15-115 beats $\mathrm{min}^{-1}$ ). The calculated percentage contribution of heart rate to increases in vं02 at $10^{\circ}, 20^{\circ}$, and $30^{\circ} \mathrm{C}$ was $4.38,188$, and 108 , respectively. Hillman et al. (1987b) also demonstrated that pulse volume remains unchanged with enforced activity in $\underline{B}$. marinus and $\underline{R}$. catesbeiana at $20^{\circ} \mathrm{C}$.

Since cardiac output contributes only modestly to thermally- and activity-induced increases in $\dot{v} 02$, it follows that $A-V$ O2 difference has been suggested as the principal means of enhancing $\dot{\mathrm{V}} 2$ in anurans (Becker et all., 197ø; Carey, 1979; Hedrick, 1985; Withers et al., 1987). This contribution of $\mathrm{A}-\mathrm{V} O 2$ difference is estimated to be 1008 , $84 \%$, and $88 \%$ for increases in $\dot{v} 02$ during maximal exercise at $10^{\circ}, 20^{\circ}$, and $30^{\circ} \mathrm{C}$, respectively (Hedrick, 1985). Withers et al. (1987) reported a contribution of 858 to vं02 during maximal activity in $\underline{B}$. marinus at $20^{\circ} \mathrm{C}$. In contrast, the only study in which the contribution of $\mathrm{A}-\mathrm{V} O 2$ difference to changes in metabolic rate was measured directly (Weathers, 1976) reported that thermally-induced changes in $\dot{v} 02$ are augmented by increased blood flow rather than increased oxygen extraction in $\underline{R}$. Catesbeiana.

Although the relative contribution to increases in $\dot{v} 02$ by $A-V$ O2 difference has been inferred, the direct measurement of $A-V$ O2 difference has been measured neither over a wide range of body temperatures nor during activity. 
This is complicated by cutaneous respiration, for venous blood saturation reflects the return of venous blood from the active tissues and the return of oxygenated blood from the cutaneous respiratory surface (Roth, 1973).

This investigation attempts to determine the influence of rest and activity, temperature, and removal of the pericardium on the separation efficiency of the aseptate anuran ventricle. In conjunction, the relative contribution of $\mathrm{A}-\mathrm{V} 02$ difference to thermally-induced, and enforced activity changes in $\dot{\mathrm{V}} 02$ will be delineated in the toad, $\underline{B}$. marinus, by direct determination of arterial and venous blood oxygen saturation. 


\section{CHAPTER II}

\section{MATERIALS AND METHODS}

\section{AN IMAL S}

Bufo marinus $(223-585 \mathrm{~g}$, mean $=409 \mathrm{~g})$ were purchased from commercial suppliers and maintained at room temperature $\left(20^{\circ} \mathrm{C}\right)$ with free access to water. No attempt was made to feed the animals or control photoperiod.

\section{SU RG ICAL PROCEDURE}

Animals were anesthetized by immersion in a solution of unbuffered tricaine methanesulfonate (MS-222, Sigma Chemical Co.). I outfitted each animal with an occluding cannula (PE 90) in the left systemic arch to obtain arterial blood samples. This was achieved via a 1-2 cm incision through the dorsal body surface posterior to the parotoid gland and lateral to the transverse processes of the vertebrae to bisect the external and internal abdominal oblique muscles. The cannula was secured in the vessel with Ethicon surgical silk $(3-\emptyset)$. Abdominal muscles and skin were sutured separately with Ethibond green braided polyester suture (4-ø) and Ethicon surgical silk (3- $)$, respectively. In addition, I implanted an occluding ventral abdominal cannula (PE 9ø) to procure venous blood samples. 
The vessel was exposed via a $\emptyset .5-1 . \emptyset \mathrm{cm}$ midventral incision posterior to the xiphisternum and parallel to the rectus abdominis muscle. This cannula was secured in the same manner used for the systemic arch cannula. Cannulae were flushed 24 h post-surgery and after each sampling with approximately $5 \emptyset$ ul of a heparinized $\emptyset .78$ saline solution. I removed the pericardial sac from four of the animals via a ventral incision (approx. $1 \mathrm{~cm}$ ) lateral to the sternum. To minimize damage to the musculature, the pectoralis, deltoid, and cutaneous pectoris muscles were reflected to expose the external and internal oblique muscles which were cut (approx. $1 \mathrm{~cm}$ ) in an anterior to posterior direction and reflected to expose the heart. The sac was then removed. The ventricle of the heart was drawn out through the incision to verify the procedure and then reinserted. The oblique muscles and the skin were then sutured separately as described above.

Bleeding was kept to a minimum in all surgical procedures through careful surgical technique and electrocoagulation. Animals were allowed to recover for at least $24 \mathrm{~h}$ before sampling.

EFFECT OF TEMPERATURE ON A-V O2 DIFFERENCE

The effects of low $\left(10^{\circ} \mathrm{C}\right)$ and high $\left(30^{\circ} \mathrm{C}\right)$ temperature on $\mathrm{A}-\mathrm{V} 02$ difference were determined for resting and active animals. The experimental procedure consisted of placing 
each individual in a covered plastic container $(29 \mathrm{~cm}$ long $\mathrm{x}$ $17 \mathrm{~cm}$ wide $\mathrm{x} 12 \mathrm{~cm}$ deep) which sat either in constant temperature baths for the $10^{\circ}$ and $30^{\circ} \mathrm{C}$ regimens, or in open air at $20^{\circ} \mathrm{C}$. Cloacal temperature was monitored with a tele-thermometer (Yellow Springs, $\mathrm{OH}$ ) and was within $\pm 2{ }^{\circ} \mathrm{C}$ of the environmental temperature.

Blood samples were taken from resting toads after two or more hours of temperature equilibration. Care was taken not to disturb the animal. Three blood samples, approximately 50 ul each, were collected anaerobically in heparinized capillary tubes from arterial and venous cannulae over a $2 \theta-3 \emptyset \mathrm{min}$ period to determine hemoglobin concentration and oxygen content. Each sample was analyzed within 2-3 min after it was drawn.

I collected arterial and venous blood samples from active toads in the same manner as above after three minutes of repeatedly flipping the animal on its back and allowing it to right itself. This is sufficient to attain vo2 max in anurans (Hillman, 1979). Blood samples were then analyzed for hemoglobin concentration and oxygen content.

\section{CUTANEOUS CONTRIBUTION TO BLOOD OXYGEN SATURATION}

To investigate the contribution of cutaneous oxygen exchange to blood oxygen saturation I placed animals in a plastic bag which covered approximately 658 of the body surface. The bag was then secured to the animal with a 
large rubber band posterior to the front limbs and anterior to the parotoid glands. The bag was filled and emptied three times with nitrogen. The nitrogen pressure was then kept above the ambient pressure by a constant flow of N2. Arterial and venous blood samples in active toads were then collected as previously described, and hemoglobin concentration and oxygen content were determined for these samples. Resting blood samples were not collected.

EFFECT OF PERICARDIAL SAC REMOVAL ON A-V O2 DIFFERENCE

After the pericardium was removed, I collected arterial and venous blood samples from active B. marinus at room temperature $\left(2 \theta^{\circ} \mathrm{C}\right)$. Each sample was analyzed for hemoglobin concentration and oxygen content.

\section{HEMOGLOBIN ASSAY}

Hemoglobin concentration (g Hb/løø ml blood) was determined for $2 \emptyset$ ul samples of blood with the use of a Bausch and Lomb Spectronic $2 \emptyset$ and a hemoglobin assay kit (catalog no. 525-A, Sigma Chemical Co.). Standard curves were generated for each assay. Within 2-3 min after it was drawn, the blood sample was placed in Drabkins reagent, with final hemoglobin determinations being made approximately $4 \mathrm{~h}$ later. 
BLOOD OXYGEN CONTENT

Oxygen content of the blood was determined with a Chemical Microsensor (Model 1201, Transidyne General Corp.) connected to an oxygen electrode (Model 730, Transidyne General Corp.). The oxygen electrode was fitted to a water-jacketed plexiglass chamber similar to that described by Tucker (1967). Chamber temperature was maintained at $22^{\circ} \mathrm{C}$ using a circulating constant temperature bath (Forma Scientific, Marietta, $\mathrm{OH})$. The chamber contained a Teflon coated stirring rod propelled by a magnetic stirrer controlled by a Transidyne General Corp. 1270 precision controller. Chamber volume (mean $=874 \pm 4$ ul) was determined by weighing a water filled $1 \mathrm{ml}$ sỳringe before and after filling the chamber with water.

The oxygen electrode was polarized in the ferricyanide-saponin solution described by Tucker (1967) at $-0.850 \mathrm{mv}$ for at least 24 hours before calibration. It was found that this equilibration greatly increased the stability of the electrode. The oxygen electrode was then calibrated using the procedure outlined by Tucker (1967). In addition, the oxygen-free standard was bubbled with nitrogen. Mean electrode drift was $-2.0 \%$ for the ambient standard and ranged from -5.8 to $1.3 \%$. However, since the zero standard drifted in the same manner and all measurements were made as the relative change in the $\mathrm{PO}$, the true error in this technique is less than that reported. 
The measurement of the oxygen content in each blood sample required that the sample chamber be filled with a degassed solution of potassium ferricyanide and saponin. The partial pressure of this solution was recorded after equilibration (approx. $2 \mathrm{~min}$ ). A 10 ul blood sample was then injected into the chamber through a small hole in the top of the chamber cover. The change in partial pressure was recorded after equilibration (approx. $1 \mathrm{~min}$ ) and used in the calculation:

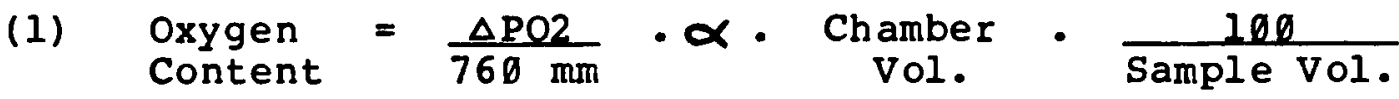
where the units for oxygen content are $\mathrm{ml} 02 / 100 \mathrm{ml}$ blood, $\alpha$ is the solubility coefficient $(0.0287)$ for oxygen in ferricyanide solution at $22^{\circ} \mathrm{C}$, and chamber and sample volumes are expressed in ul.

\section{CALCULATIONS}

Oxygen content was divided by hemoglobin concentration to give $\mathrm{ml} 02 / \mathrm{g} \mathrm{Hb}$. This value was then divided by the hemoglobin 02 capacity value of $1.34 \mathrm{ml} \mathrm{02/g} \mathrm{Hb}$ (Guyton, 1981) to yield percent saturation. A-V O2 difference was taken to be the difference in the 8 saturation of the arterial and venous blood.

Calculation of separation efficiency of the undivided ventricle is complicated. The equation used by Tazawat al. (1979) for minimal separation efficiency has been 
abandoned in this study on the basis that it describes oxygen utilization rather than separation efficiency. However, a minimal separation efficiency (Es) can be calculated, assuming that systemic venous return and pulmonary venous return are not equal and account for 628 and 388 (Tazawa et at., 1979) of the blood returning to the heart, respectively, by the following equation:

$$
E s=\frac{S a-\frac{1100 \times .76+S v \times 1.24)}{2}}{100-\frac{(100 \times .76+S v \times 1.24)}{2}} \times 100
$$

where $\mathrm{Sa}=$ measured arterial \& saturation and $\mathrm{Sv}=$ measured venous \& saturation. This equation is based on the assumption that left atrial blood is 1008 saturated with oxygen. If left atrial blood is less than 1008 saturated than Es is greater then calculated. If Sv greater than Sa then Es will be negative.

\section{STATISTICS}

Means and 958 confidence intervals are presented. A one-way ANOVA and Scheffe's multiple comparison test were used to determine significance of differences between three or more means (zar, 1984). Paired t-tests were used to determine significant differences between two means. The minimal level of significance was taken as $P<.05$. 
CHAPTER III

\begin{abstract}
RESULTS
HEMOGLOB IN CONCENTRATION, \& SATURATION AND $A-V$ O2 DIFFERENCE
\end{abstract}

Means and 958 confidence intervals for hemoglobin concentration, s saturation of arterial and venous blood, and $A-V O 2$ difference for resting and active $B$. marinus at different body temperatures are presented in Table I. The site of blood sampling is not critical in the determination of hemoglobin concentration, as shown by the lack of a significant difference $(p>.05)$ between arterial and venous hemoglobin concentrations in both resting and active animals at each temperature (Figure 1). In addition, I observed no significant difference $(p>.05)$ between resting arterial and venous hemoglobin concentrations in toads at $10^{\circ}$ and $20^{\circ} \mathrm{C}$, nor between toads at $20^{\circ}$ and $30^{\circ} \mathrm{C}$. However, arterial and venous hemoglobin concentrations in resting toads at $10^{\circ} \mathrm{C}$ were significantly lower $(p<.05)$ than arterial hemoglobin concentration in toads at $30^{\circ} \mathrm{C}$. In contrast, the activity status, and secondarily, body temperature influenced hemoglobin concentration. Arterial and venous hemoglobin concentrations in active $\underline{B}$. marinus at all three temperatures were significantly higher $(p<.05)$ than previous 


\section{TABLE I}

EFFECT OF BODY TEMPERATORE ON. BLOOD HEMOGLOB IN CONCENTRATION AND SATURATION PARAMETERS IN RESTING

AND ACTIVE Bufo marinus

\begin{tabular}{|c|c|c|c|c|c|}
\hline \multicolumn{2}{|c|}{ Condition } & & $\begin{array}{c}\text { Hemoglobin } \\
(\mathrm{g} \quad \mathrm{Hb} / \mathrm{I} \theta 6 \mathrm{gl})\end{array}$ & $\begin{array}{c}\text { Hemoglobin } \\
\text { Saturation } \\
\text { (\&) }\end{array}$ & $\begin{array}{l}\text { Arterio- } \\
\text { venous } \\
\text { Difference } \\
\text { (8 Sate) }\end{array}$ \\
\hline \multirow{6}{*}{ Rest } & \multirow{2}{*}{$10^{\circ} \mathrm{C}$} & Art. & $4.5(4.1-5.0)$ & $84(79-90)$ & \multirow{2}{*}{$10(2.8-17)$} \\
\hline & & Ven. & $4.6(4.2-5.0)$ & $75(7 \emptyset-8 \theta)$ & \\
\hline & \multirow{2}{*}{$20^{\circ} \mathrm{C}$} & Art. & $4.7(4.1-5.3)$ & $98(94-101)$ & \multirow{2}{*}{$19(10-28)$} \\
\hline & & Ven. & $4.8(4.1-5.5)$ & $78(71-86)$ & \\
\hline & \multirow{2}{*}{$30^{\circ} \mathrm{C}$} & Art. & $6.3(5.8-6.9)$ & $93(91-95)$ & \multirow{2}{*}{$19(13-24)$} \\
\hline & & Ven. & $5.7(5.3-6.2)$ & $75(70-79)$ & \\
\hline \multirow{6}{*}{ Active } & \multirow{2}{*}{$10^{\circ} \mathrm{C}$} & Art. & $7.1(6.5-7.8)$ & $97(93-101)$ & \multirow{2}{*}{$68(62-74)$} \\
\hline & & Ven. & $8.1(7.4-8.7)$ & $29(25-32)$ & \\
\hline & \multirow{2}{*}{$20^{\circ} \mathrm{C}$} & Art. & $8.9(8.3-9.5)$ & $93(90-96)$ & \multirow{2}{*}{$55(5 \theta-61)$} \\
\hline & & Ven. & $8.5(8.0-9.0)$ & $38(32-43)$ & \\
\hline & \multirow[t]{2}{*}{$30^{\circ} \mathrm{C}$} & Art. & $8.7(8.2-9.3)$ & $74(71-77)$ & \multirow[t]{2}{*}{$50(47-53)$} \\
\hline & & Ven. & $8.1(7.6-8.5)$ & $26(22-3 \theta)$ & \\
\hline
\end{tabular}

* Means and 958 confidence intervals are presented. Mean $v$ alues are based on 24 determinations ( 8 animals, 3 determinations per animal). 


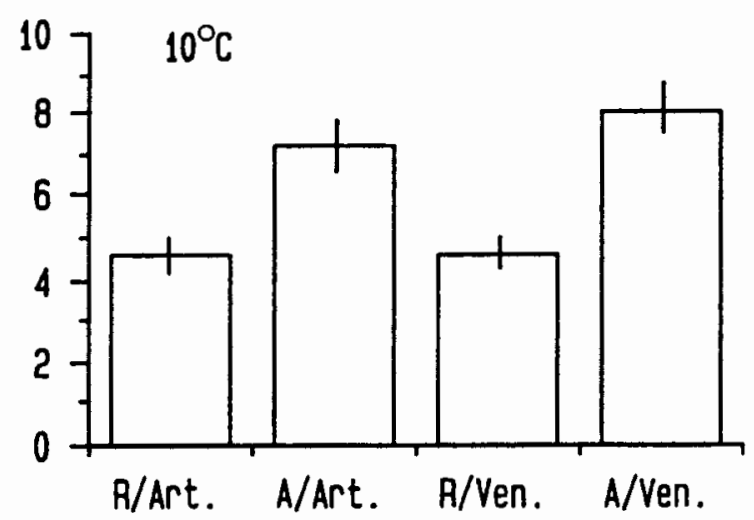

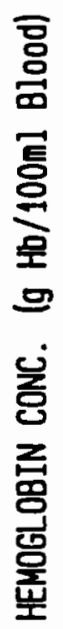
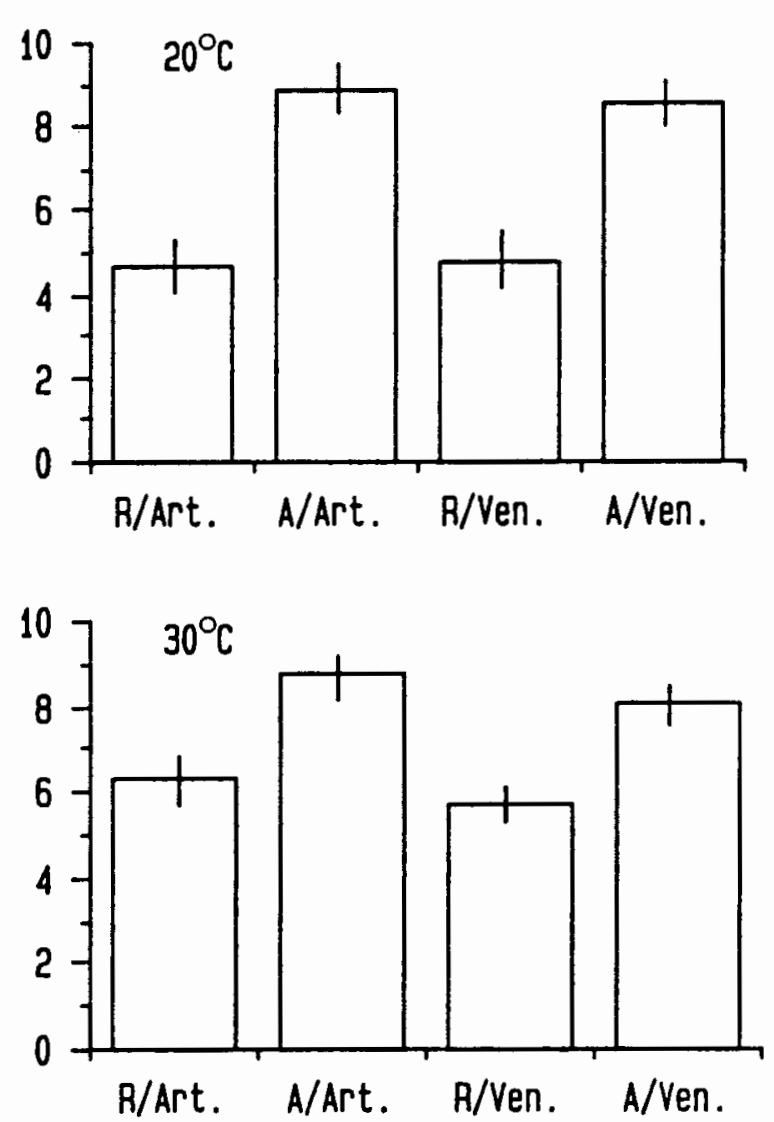

Figure 1. Arterial (Art.) and venous (Ven.) blood hemoglobin concentration ( $\mathrm{g} \mathrm{Hb} / 100 \mathrm{ml}$ ) during rest ( $R$ ) and activity ( $A$ ) at different body temperatures in $B$. marinus. Means and $95 \%$ confidence intervals are presented. 
resting levels (Figure 1). Active arterial and venous hemoglobin concentrations were not significantly different (p>.ø5) among temperatures, except that arterial hemoglobin concentrations of active toads at $10^{\circ} \mathrm{C}$ were significantly lower $(p<.05)$ than those of toads at $20^{\circ} \mathrm{C}$.

Body temperature influences neither resting arterial nor active venous \& saturation. However, low and high body temperatures appear to affect resting venous and active arterial 8 saturation, respectively. There was no significant difference $(p>05)$ between arterial and venous 8 saturation in resting B. marinus at $10^{\circ} \mathrm{C}$. However, venous $\%$ saturation was significantly lower $(p<. \emptyset \emptyset 1)$ than arterial 8 saturation in resting animals at $20^{\circ}$ and $30^{\circ} \mathrm{C}$ (Figure 2). There was no significant difference $(p>.05)$ in resting arterial $\&$ saturation at all three temperatures. Arterial 8 saturation remained elevated during activity in B. marinus at $10^{\circ}$ and $20^{\circ} \mathrm{C}$ and was not significantly different ( $p>.05$ ) than previous resting levels. In contrast, arterial 8 saturation in active animals at $30^{\circ} \mathrm{C}$ was significantly lower $(p<. \emptyset \emptyset 1)$ than resting arterial o saturation at this temperature (Figure 2). Venous 8 saturation dropped with activity (Figure 2). There was a significant difference $(p<. \emptyset \emptyset 1)$ between active and resting venous $\&$ saturation at all three temperatures. However, there was no significant difference $(p>. \emptyset 5)$ in active venous $\&$ saturation between temperatures. 

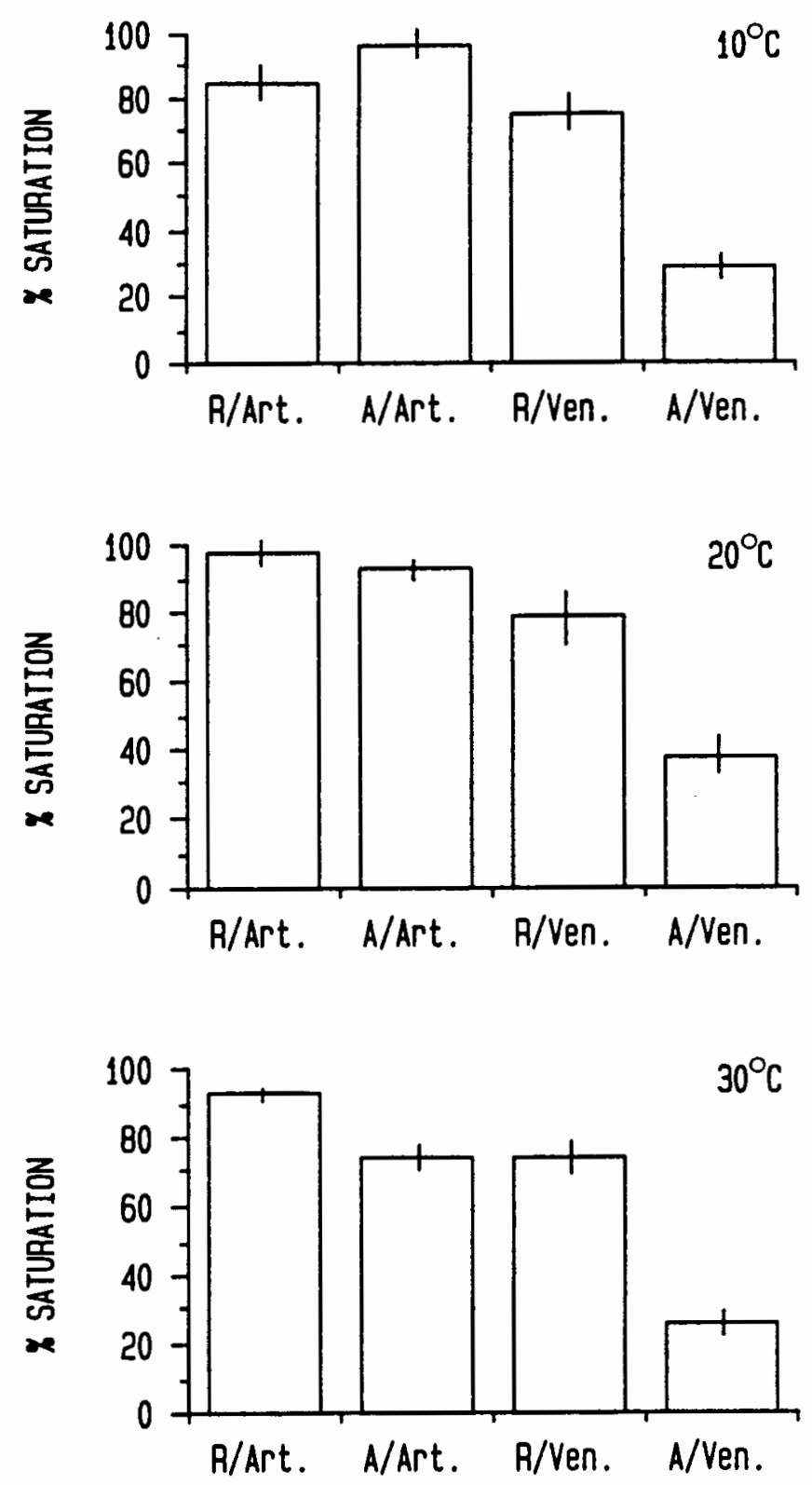

Figure 2. Arterial (Art.) and venous (Ven.) blood hemoglobin saturation (\% saturation) during rest ( $R$ ) and activity (A) at different body temperatures in B. marinus. Means and 95\% confidence intervals are presented. 
The contribution of $\mathrm{A}-\mathrm{V} O 2$ difference to thermally induced changes in VO2 remained constant in resting toads. However, oxygen extraction played an important role in supporting activity-induced changes in VO2. Resting $\mathrm{A}-\mathrm{V} \mathrm{O} 2$ differences were not significantly different ( $p>05)$ among the three temperatures (Figure 3 ). However, active $\mathrm{A}-\mathrm{V} 02$ differences were significantly greater $(p<. \emptyset \emptyset 1)$ than corresponding resting levels at all three temperatures. The magnitude of this increase ranged from a 2.6-fold increase in B. marinus at $30^{\circ} \mathrm{C}$ to a 6.8 -fold $\mathrm{rise}$ in toads at $10^{\circ} \mathrm{C}$ (Table I). The $A-V$ O2 difference in active $B$. marinus at $10^{\circ} \mathrm{C}$ was significantly greater $(p<.05)$ than that of toads at $20^{\circ}$ and $30^{\circ} \mathrm{C}$ (Figure 3 ). No significant difference (P>.05) in $\mathrm{A}-\mathrm{V}$ O2 difference was noted during activity in animals at $20^{\circ}$ and $30^{\circ} \mathrm{C}$.

\section{CUTANEOUS CONTRIBUTION TO BLOOD OXYGEN SATURATION}

Means and 958 confidence intervals for hemoglobin concentration and $z$ saturation of arterial and venous blood, along with $A-V O 2$ difference, for active $\underline{B}$. marinus exposed cutaneously to ambient air and nitrogen environments at $2 \emptyset^{\circ} \mathrm{C}$ are presented in Table II. The elimination of cutaneous respiration caused a decrease in the venous of saturation which is reflected in an increased $\mathrm{A}-\mathrm{V} O 2$ difference in active B. marinus. Arterial 8 saturation in toads exposed to ambient air was significantly greater $(p<. \emptyset 1)$ than 


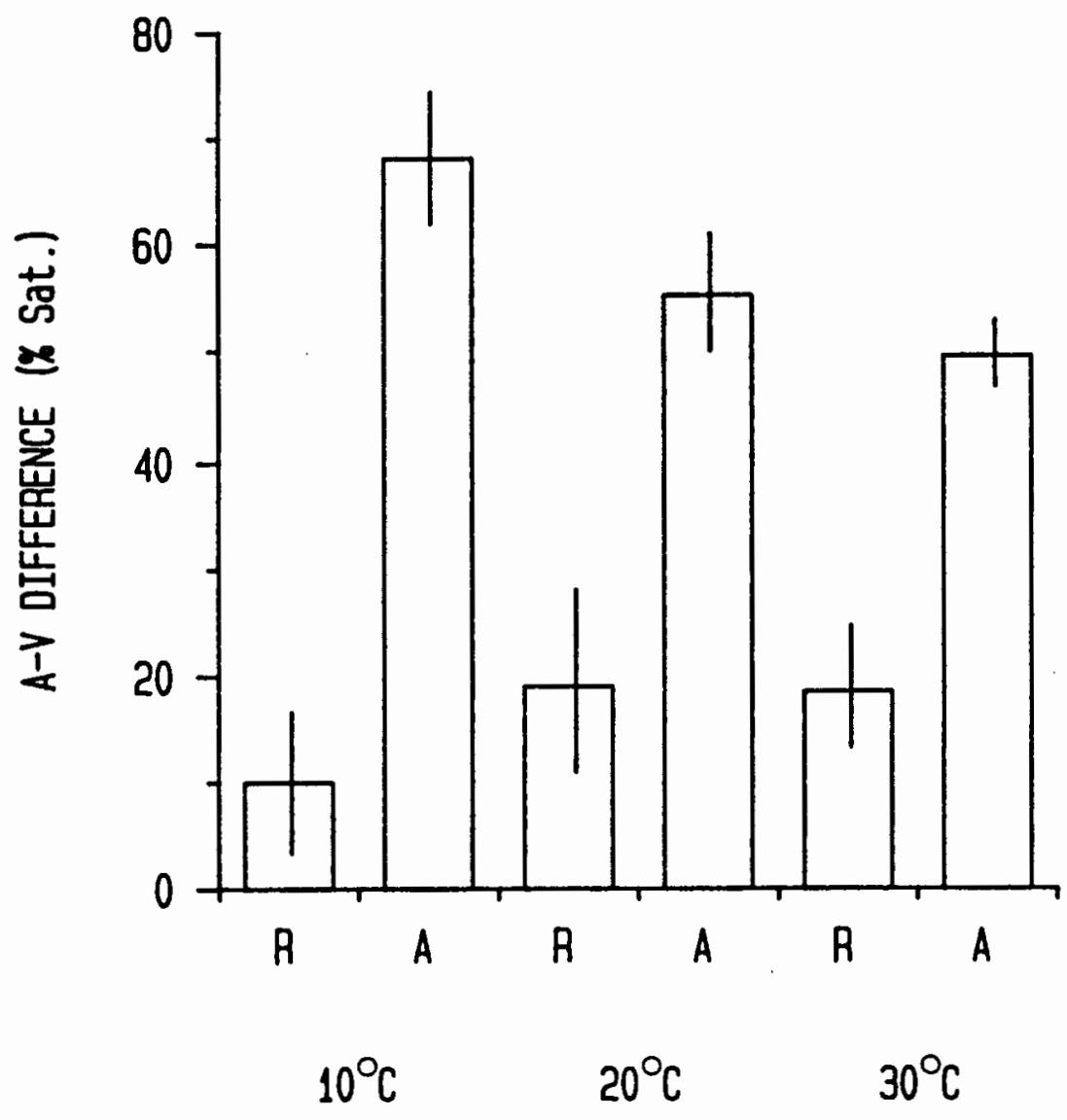

Figure 3. Arteriovenous 02 difference during rest $(R)$ and activity (A) at different body temperatures in $B$. marinus. Means and 95\% confidence intervals are presented. 


\section{TABLE II}

EFFECT OF AMBIENT AIR AND NITROGEN ENVIRONMENTS ON BLOOD BEMOGLOB IN CONCENTRATION AND SATURATION

PARAMETERS IN ACTIVE Bufo marinus

\begin{tabular}{lllll} 
Condition & & $\begin{array}{c}\text { Hemoglobin } \\
\text { (g Hb/lg0 mI) }\end{array}$ & $\begin{array}{c}\text { Hemoglobin } \\
\text { Saturation } \\
(8)\end{array}$ & $\begin{array}{c}\text { Arterio- } \\
\text { venous } \\
\text { Difference } \\
(8 \text { Sat. })\end{array}$ \\
\hline \multirow{2}{*}{ Ambient Air } & Art. & $7.8(7.1-8.2)$ & $83(80-87)$ & \\
& Ven. & $7.0(6.5-7.5)$ & $26(22-31)$ & $57(51-64)$ \\
\multirow{2}{*}{ Nitrogen } & Art. & $7.2(6.6-7.7)$ & $79(75-83)$ & $65(60-71)$ \\
\hline
\end{tabular}

* Means and 958 confidence intervals are presented. Mean values are based on 21 determinations ( 7 animals, 3 determinations per animal). 
arterial \& saturation when the integument was exposed to a nitrogen environment. In addition, venous 8 saturation was significantly lower $(p<. \emptyset \emptyset 1)$ in toads exposed cutaneously to a nitrogen atmosphere (Figure 4). In the nitrogen environment, venous \& saturation was reduced approximately 128 from that in ambient air. This change in venous 8 saturation was reflected in an increase of the $A-V 02$ difference, which was significantly higher $(p<. \emptyset \emptyset 1)$ in $\underline{B}$. marinus exposed to a nitrogen environment.

EFFECT OF PERICARDIAL SAC REMOVAL ON A-V O2 DIFFERENCE

Means and 958 confidence intervals for hemoglobin concentration, \& saturation of arterial and venous blood, and $\mathrm{A}-\mathrm{V} 02$ difference for active $\mathrm{B}$. marinus at $20^{\circ} \mathrm{C}$, intact and with the pericardium removed, are presented in Table III. There was no significant difference (p>.05) in arterial \& saturation, venous \& saturation, or $\mathrm{A}-\mathrm{V} 02$ difference in animals with or without a pericardium (Figure 5).

\section{SEPARATION EFFICIENCY}

Low body temperature lowered Es in resting toads. Es was relatively high in resting animals at $20^{\circ}$ and $30^{\circ} \mathrm{C}$ and in active toads at low body temperature. Es remained unchanged with activity at higher body temperatures. The calculated minimal Es was significantly reduced $(p<. \emptyset 5)$ in 

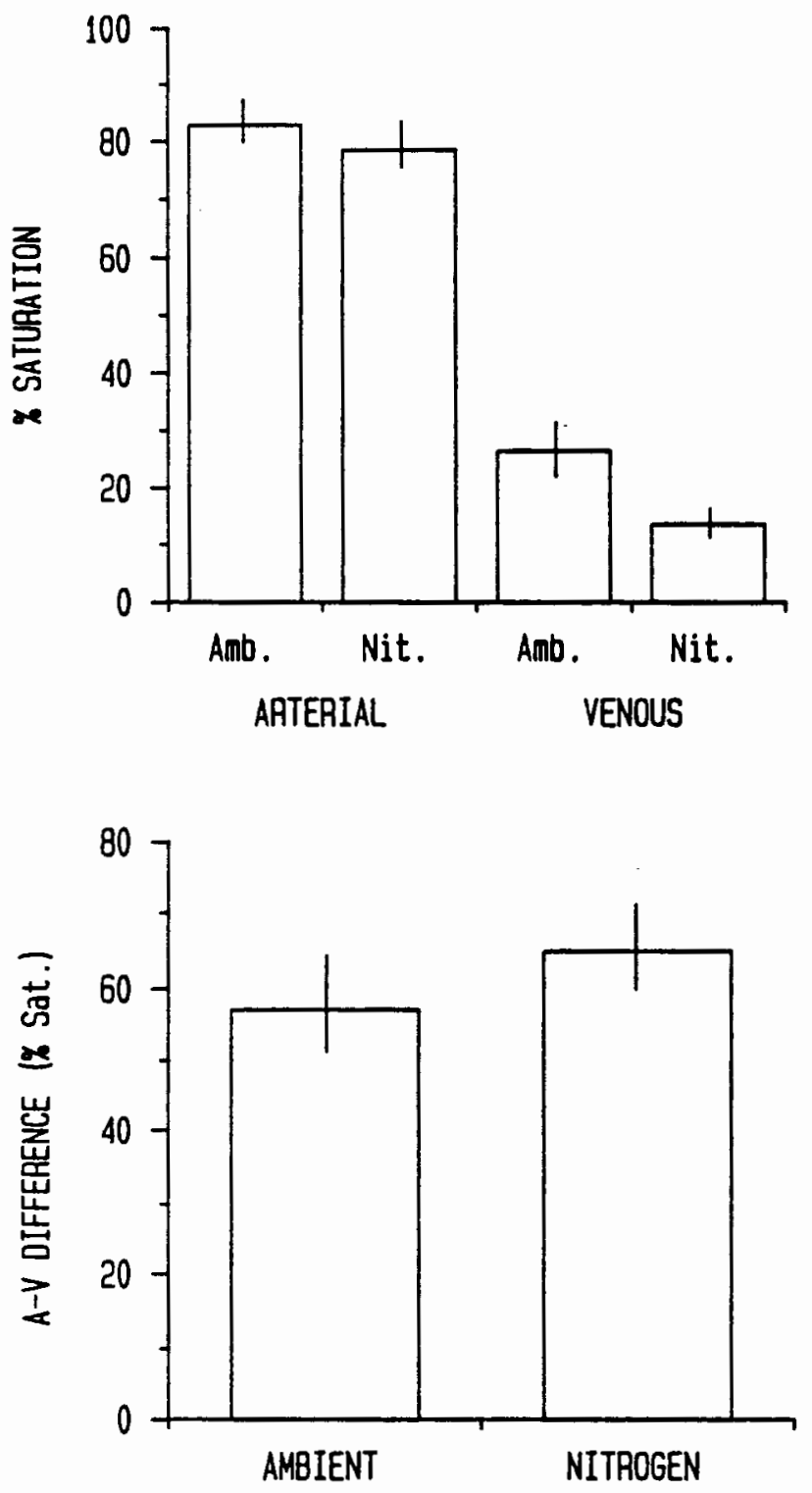

Figure 4. Blood hemoglobin saturation (\% saturation) and arteriovenous 02 difference in active $B$. marinus exposed to ambient air (Amb.) and nitrogen (Nit.) environments at $20^{\circ} \mathrm{C}$. Means and $95 \%$ confidence intervals are presented. 


\section{TABLE III}

\section{EFFECT OF PERICARDIAL SAC REMOVAL ON HEMOGLOBIN CONCENTRATION AND SATURATION PARAMETERS IN ACTIVE Bufo marinus}

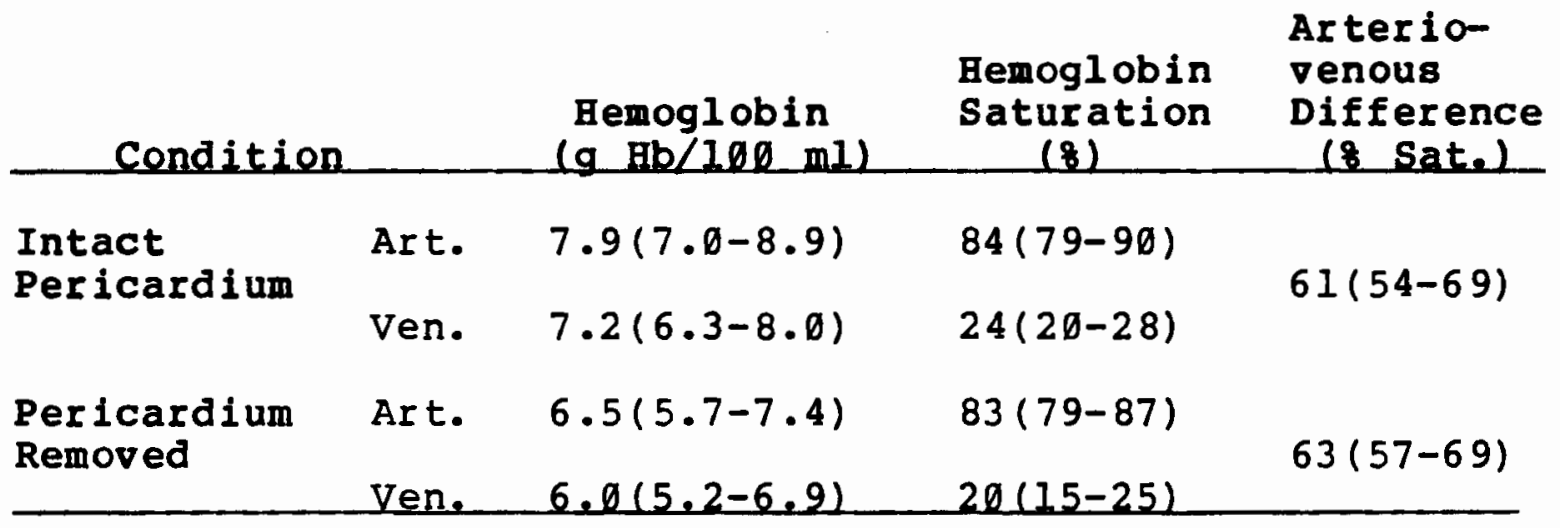

* Means and 958 confidence intervals are presented. Mean values are based on 12 determinations ( 4 animals, 3 determinations per animal). 

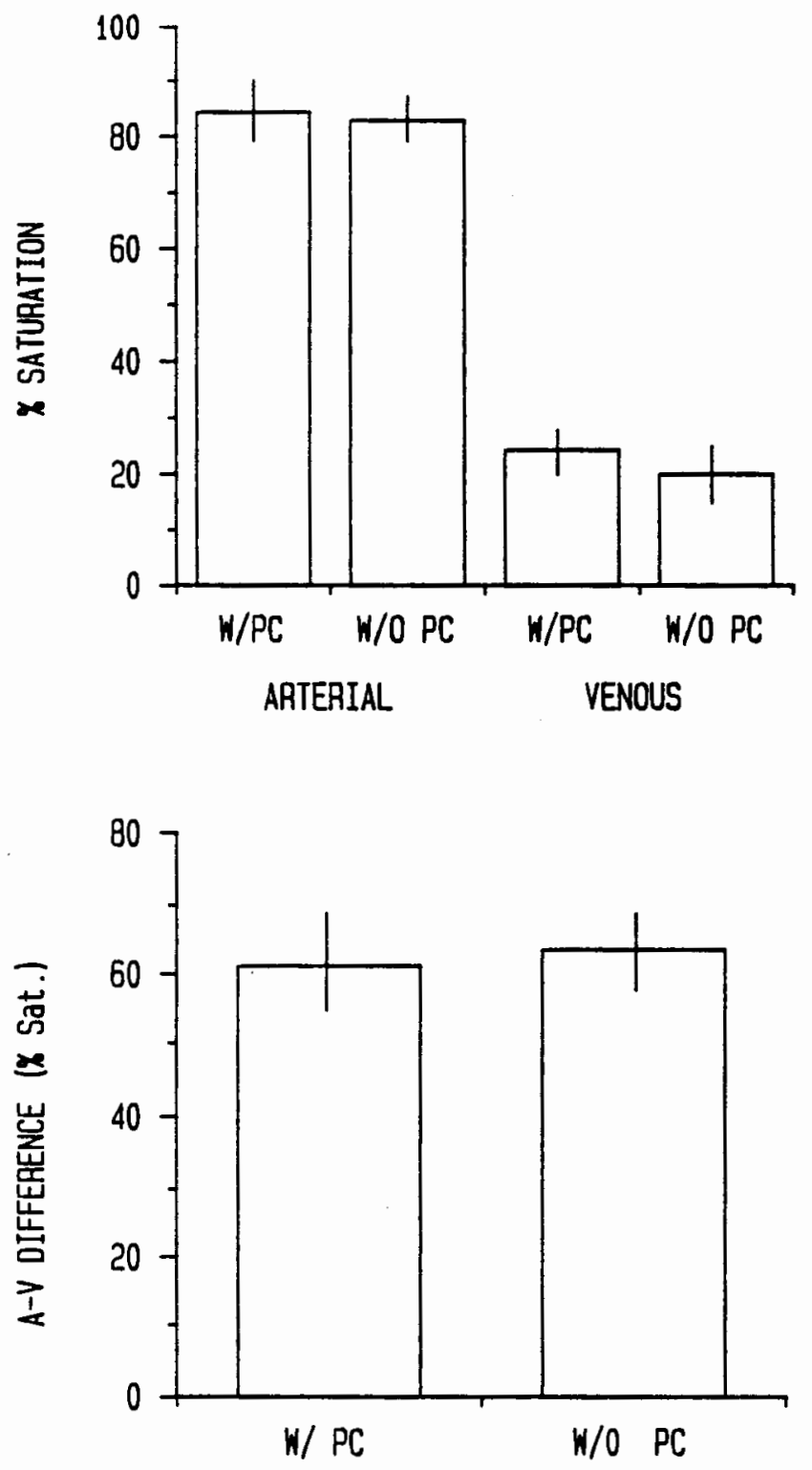

Figure 5. Blood hemoglobin saturation (\% saturation) and arteriovenous 02 difference in active $B$. marinus with intact (W/PC) and surgically removed pericardium (W/O PC) at $20^{\circ} \mathrm{C}$. Means and $95 \%$ confidence intervals are presented. 
resting B. marinus at $10^{\circ} \mathrm{C}$ from that of toads at $20^{\circ}$ and $30^{\circ} \mathrm{C}$ (Figure 6). Es in resting toads at $20^{\circ}$ and $30^{\circ} \mathrm{C}$ was 608 and 458 , respectively. There was no significant difference $(p>. \emptyset 5)$ between resting Es of animals at $2 \emptyset^{\circ}$ and $30^{\circ} \mathrm{C}$. Es was significantly elevated $(p<.05)$ from rest $(-5.08)$ in active (858) B. marinus at $10^{\circ} \mathrm{C}$ (Figure 6 ). However, there was no significant difference ( $p>.05)$ between resting and active Es of toads at $20^{\circ}$ and $30^{\circ} \mathrm{C}$. Furthermore, there was no significant difference ( $p>.05$ ) between Es of active animals at $10^{\circ}$ and $20^{\circ} \mathrm{C}$. The Es of active toads at $10^{\circ}$ and $20^{\circ} \mathrm{C}$ was significantly higher than that of active toads at $30^{\circ} \mathrm{C}$. Pericardial sac removal had no effect $(p>. \emptyset 5)$ on Es in active $\underline{B}$. marinus at $20^{\circ} \mathrm{C}$ (Figure 7). 

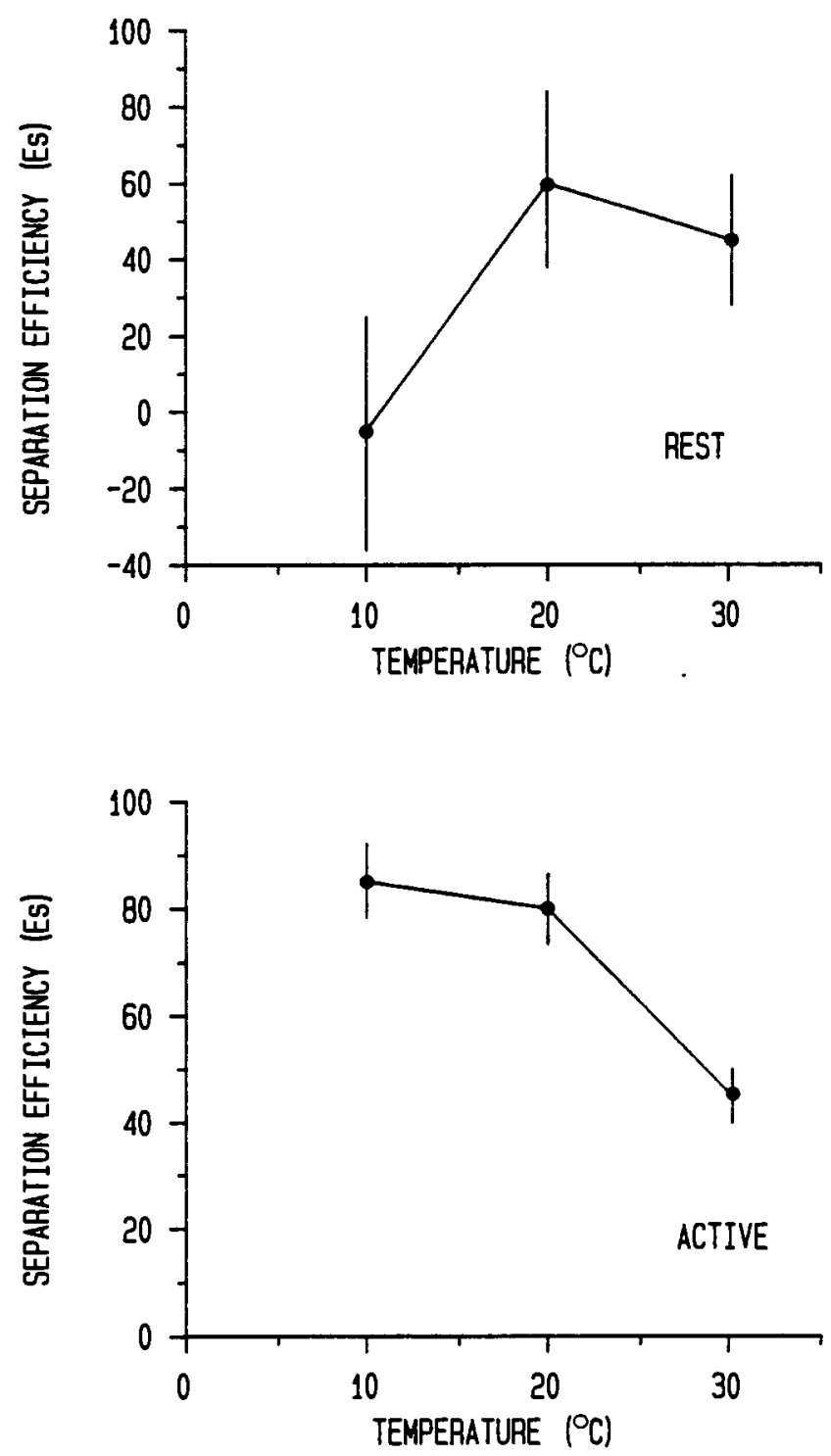

Figure 6. Separation efficiency (Es) as a function of temperature $\left({ }^{\circ} \mathrm{C}\right)$ in resting and active B. marinus. Means and $95 \%$ confidence intervals are presented. 


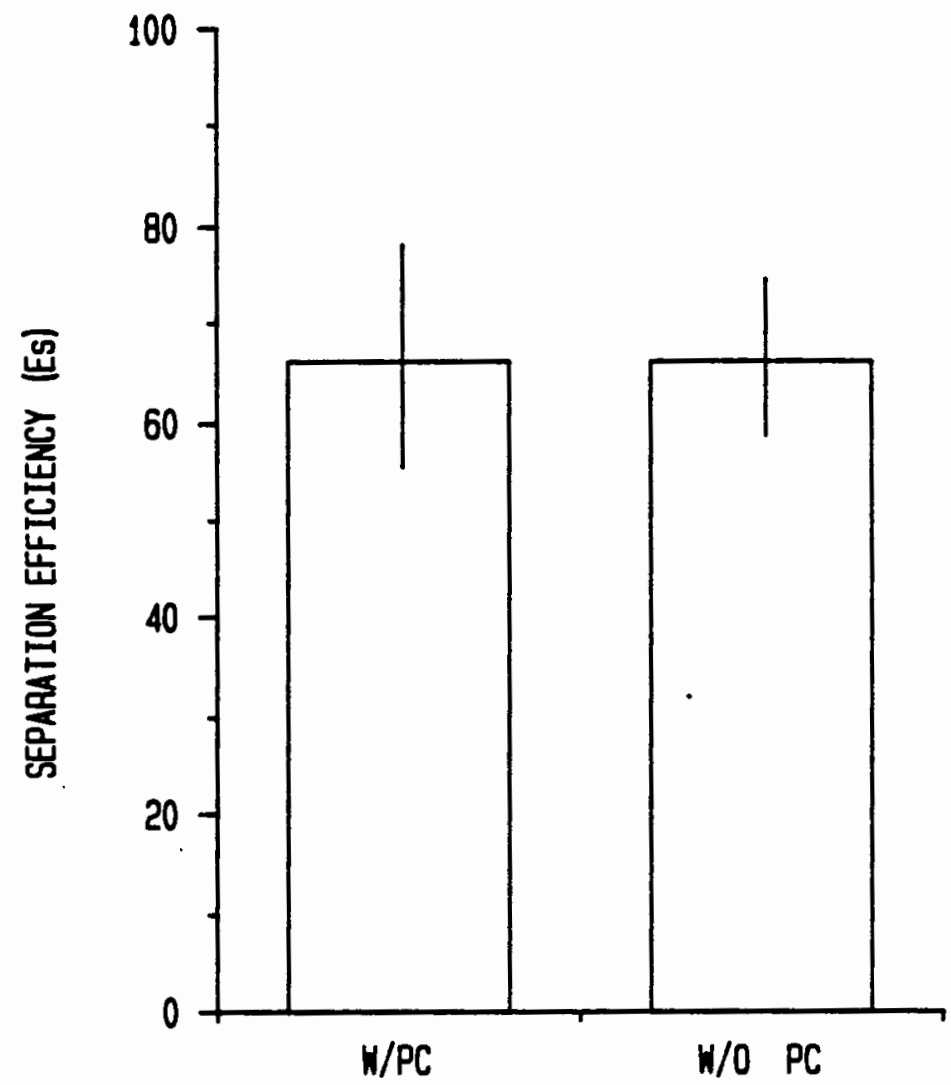

Figure 7. Effect of intact (W/PC) and pericaraial sac removal (W/O PC) on separation efficiency (Es) in active $\mathrm{B}$. marinus at $20^{\circ} \mathrm{C}$. Means and $95 \%$ confidence intervals are presented. 


\section{CHAPTER IV}

\section{DISCUSSION}

This analysis of the separation efficiency of the anuran ventricle, along with the relative contribution of A-V O2 difference to thermally- and activity-induced changes in VO2, introduces a problem not yet fully recognized in anuran cardiovascular physiology. There was a 1.4- to 1.9-fold increase in blood hemoglobin concentration and therefore oxygen content with enforced activity, the magnitude of this increase was dependent on the activity status of the animal (Table I). Animals at $30^{\circ} \mathrm{C}$, which exhibited irritability with the resting protocol, experienced the smallest increase in hemoglobin concentration. Tufts et al. (1987) reported a 1.5-fold increase in hematocrit (HCt) of B. marinus at $22^{\circ} \mathrm{C}$ following a 30 minute bout of exercise. A 1.4-fold increase in Hct has been observed in B. marinus exercising at $25^{\circ} \mathrm{C}$ (McDonald et al., 1980) and in X. Laevis (Boutilier et all., 1986). Handling stress (MbangKollo and de Roos, 1983) and the administration of epinephrine and norepinephrine (Herman, 1977; MbangKollo and de Roos, 1983) have also been implicated in elevating Hct in R. catesbeiana. 
A direct comparison can be made of the increase in hemoglobin concentration I measured with previous changes reported in Hct following activity. Experiments have shown that activity-induced increases in Hct are not the result of erythrocyte swelling (Tufts et al., 1987). Moreover, B. marinus and R. catesbeiana have been shown to defend red blood cell volume over a wide range of osmotic concentrations (zygmunt, 1984). This investigation supports the hypothesis that the increase in hemoglobin concentration with enforced activity is a result of an increase in the circulating number of erythrocytes relative to plasma, a conclusion also reached by Tufts et al. (1987).

Several physiological mechanisms have been proposed to account for this hemoconcentration with administration of catecholamines and enforced activity. Although Boutilier et al. (1986) make an argument for the uptake of plasma during activity by osmotically rich muscle cells, there are discrepancies in their data, as noted by the authors. The mobilization of stored erythrocytes from the spleen and/or visceral reservoirs has also been suggested (MbangRollo and de Roos, 1983). However, it seems unlikely that the magnitude of the changes in hemoglobin concentration I measured during activity can be accounted for by this diminutive organ and its meager erythrocyte reservoir (personal observation). Hillman et all. (1987a) have recently shown that the balance of forces in the anuran 
vascular system favor ultrafiltration in the capillary beds, even at rest. Increases in blood pressure during activity would augment this process. Thus, a loss of plasma volume via ultrafiltration may account for the rise in hemoglobin concentration during activity. This fluid could then be returned to the vascular space via the lymphatic system during recovery. Baustian (1986) reported that B. marinus can fully recover from an acute loss of 208 of blood volume within 20 min by mobilization of extra-vascular lymph. This mechanism could return hemoglobin concentration to normal resting levels in a relatively short period of time. Tufts et al. (1987) report that Hct returned to pre-exercise levels within $l \mathrm{~h}$.

Considering the hemoconcentration which results from increased activity in B. marinus, comparisons of blood oxygen content between animals at rest and during activity are misleading when only absolute concentrations of oxygen are reported. A more appropriate method would be to take into account changes in hemoglobin concentration with activity and to express oxygen content as 8 saturation. The values for mean resting arterial \& saturation (84-98\%) are similar to those previously reported in the literature for B. marinus (Withers et all., 1987), B. paracnemis (Johansen and Ditadi, 1966), and R. catesbeiana (Tazawa et all., 1979) at room temperature. Temperature had no effect on resting arterial o saturation. This contrasts 
with Weathers's (1976) report of a decrease in arterial 8 saturation in $R$. catesbeiana acclimatized to $20^{\circ} \mathrm{C}$ compared to that of animals at $5^{\circ} \mathrm{C}$. However, it should be noted that the values for heart rate reported by weathers (1976) for supposedly resting animals correspond to those reported for active R. Catesbeiana (Hillman et al., 1987b).

Mean arterial \& saturation of active B. marinus at $10^{\circ}$ and $20^{\circ} \mathrm{C}$ were not different from resting values, whereas saturation declined in animals at $30^{\circ} \mathrm{C}$. Considering the high heart rates in active toads at $30^{\circ} \mathrm{C}$ (Hedrick, 1985), this reduction in arterial saturation is most likely due to admixture of systemic venous and pulmonary blood in the aseptate venticle of $\underline{B}$. marinus as a result of decreased filling time.

At rest, mean venous $\&$ saturation in animals at $10^{\circ} \mathrm{C}$ resembled that of resting arterial 8 saturation. Resting venous $\&$ saturation of toads at $20^{\circ}$ and $30^{\circ} \mathrm{C}$ in this investigation correspond to values reported for $\underline{B}$. marinus at $20^{\circ} \mathrm{C}$ (Withers et al., 1987). Activity caused a decrease in venous of saturation at all three temperatures (Figure 2). Withers et al. (1987) reported a similar reduction in venous 8 saturation in $\underline{B}$. marinus at $20^{\circ} \mathrm{C}$ with enforced activity. It is interesting to note that open chest point microsampling techniques reveal reduced venous \& saturation in B. paracnemis (Johansen and Ditadi, 1966) and $\underline{R}$. catesbeiana (Tazawa et al., 1979) similar to values reported 
here and to those reported by Withers et al. (1987) for active B. marinus.

Resting $A-V 02$ difference was the same in toads at all three temperatures (Figure 3). Therefore, thermally-induced changes in resting vंO2 could be accounted for by changes in blood flow as reported by Weathers (1976). However, caution should be used in comparing the results of this investigation to those of Weathers (1976), since the heart rates reported by Weathers suggest the animals were not at rest.

The decrease in venous $\&$ saturation with activity at all three temperatures increased the $\mathrm{A}-\mathrm{V}$ O2 difference (Figure 3), with the greatest increase at $10^{\circ} \mathrm{C}$. Thus, the increase in $\dot{v} 02$ associated with activity results primarily from an increase in oxygen extraction, verifying hypotheses formulated by other authors (Becker et al., 1970; Carey, 1979 ; Hedrick, 1985; Withers et al., 1987).

Active arterial \& saturation in toads exposed cutaneously to a nitrogen environment was less than when the integument was exposed to ambient air, but the magnitude of this change was only slight $(48)$. This reduction in arterial s saturation may be due to the inhalation of nitrogen during the experimental procedure, even though I tried to eliminate respiratory contamination, or ventricular admixture. The decrease in venous of saturation (128 reduction) of active toads exposed cutaneously to a nitrogen 
environment gives the first reported contribution of cutaneous respiration to venous of saturation (Figure 4). This is a conservative estimate, however, because the entire cutaneous respiratory surface was not exposed to the nitrogen environment. Although arterial $\&$ saturation was reduced in animals exposed cutaneously to nitrogen, the large decrease in venous $\&$ saturation resulted in an increased $A-V$ O difference of active toads under these conditions.

Using Hedricks (1985) blood flow rates and vo2 measurements for resting and active $\underline{B}$. marinus at $10^{\circ}, 20^{\circ}$, and $30^{\circ} \mathrm{C}$, an attempt was made to determine the relative contributions of the product of blood flow rate and $A-V O 2$ difference to thermally- and activity-induced changes in vं02. It was found that 418,718 , and 678 of the resting $\dot{\mathrm{v}} 02$ at $10^{\circ}, 20^{\circ}$, and $30^{\circ} \mathrm{C}$, respectively, could be accounted for by this product. During activity the values change to 658 , $85 \%$, and $34 \%$ for animals at $10^{\circ}, 20^{\circ}$, and $30^{\circ} \mathrm{C}$, respectively. Taking into account cutaneous respiration by increasing the $A-V O 2$ differences by 128 , the values for resting $\underline{B}$. marinus at $10^{\circ}, 20^{\circ}$, and $30^{\circ} \mathrm{C}$ increase to 898 , $118 \%$, and 838 and those for activity increase to $105 \%, 100 \%$, and 418 in animals at $10^{\circ}, 20^{\circ}$, and $30^{\circ} \mathrm{C}$, respectively. Withers et al. (1987) predicted 348 of the increase in vं02 could be accounted for by the product of blood flow rate and $\mathrm{A}-\mathrm{V}$ O2 difference in active toads at $20^{\circ} \mathrm{C}$. However, the 
value of such predictions is questionable. First, the blood flow rates reported by Hedrick (1985) are only for the systemic arches; the measurement of stroke volume by blood flow is presently not possible. Second, since the measurement of stroke volume remains elusive, it is important to know the contribution to vo2 by the musculature receiving blood via the systemic arches, which has not been elucidated. Third, hemoglobin concentrations were not measured for the animals used by Hedrick (1985); as previously mentioned, these values are important when considering thermally- or activity-induced changes in $\dot{v} 02$ in B. marinus. Moreover, the contribution of cutaneous respiration to venous saturation during rest would decrease due to a decrease in the gradient for the flux of oxygen to the vasculature. The only way to determine the relative contributions of blood flow rate and $A-V O 2$ difference is to obtain $\dot{\mathrm{V}} 2$, heart rate, stroke volume, and $\mathrm{A}-\mathrm{V} \mathrm{O} 2$ difference from the same animal, which presently is not possible. However, it is important to understand that al though complications remain in estimating the relative contribution of blood flow and $A-V$ O2 difference to changes in $\dot{V} 02$, increased oxygen extraction plays a central role to augment activity-induced changes in $\dot{v} 02$.

Using assumptions noted earlier (see methods) minimal Es was -5.08 in resting $\underline{B}$. marinus at $10^{\circ} \mathrm{C}$. However, resting Es in toads at $20^{\circ}$ and $30^{\circ} \mathrm{C}$ improved to 608 and $45 \%$, 
respectively (Figure 6). Activity elevated Es in animals at $10^{\circ} \mathrm{C}$ to 858 while Es in toads at $20^{\circ}$ and $30^{\circ} \mathrm{C}$ was not statistically different at 798 and $45 \%$, respectively. The decreasd $\mathrm{Es}$ in resting toads at $10^{\circ} \mathrm{C}$ may be the result of decreased heart rates (Hedrick, 1985) in animals at this body temperature. This results in a decreased transit time of blood passing through the heart, allowing increased time for admixture of systemic venous return and left atrial output. In addition, the huddling posture of toads at low body temperature may play a role in disrupting flow through the ventricle. Furthermore, the decrease in vo2 (Hedrick, 1985) and elevated venous \& saturation in toads at low body temperature may not necessitate selective shunting of atrial outputs. It is possible that the decrease in Es of toads at $30^{\circ} \mathrm{C}$ may result from elevated heart rates at this temperature (Hedrick, 1985), which disrupt cardiac shunting efficiency and thus reduce arterial $z$ saturation.

Withers et al. (1987) reported resting separation efficiency (288) in B. marinus to be lower than the values reported here, while separation efficiency during activity (838) was higher than the values for toads at $20^{\circ} \mathrm{C}$ in this investigation. This is because withers et al. (1987) utilized a calculation derived by Tazawa et al. (1979) which, in my opinion, incorrectly describes separation efficiency and more accurately characterizes oxygen utilization. Therefore, this equation predicts a decreased 
separation efficiency for resting animals while separation efficiency of active animals is elevated.

Using data from Withers et al. (1987) and the calculation I derived for Es, resting Es becomes 77 while Es during activity increases to $87 \%$. Although these values are elevated compared to those for toads at $20^{\circ} \mathrm{C}$ in this investigation, it provides further evidence that the Es of the aseptate ventricle is high. Data from Johansen and Ditadi (1966) for B. paracnemis and from Tazawa et al. (1979) for R. catesbeiana yield similar Es values when utilizing the equation derived in this study. In contrast to the findings of Tazawa et al. (1979), I found no effect of pericardial sac removal on Es in active $\underline{B}$. marinus at $2 \emptyset^{\circ} \mathrm{C}$ (Figure 7 ).

In summary, these data support the contention that the anuran ventricle selectively shunts atrial outputs during rest and activity and that this selective shunting is disrupted in resting $\underline{B}$. marinus at low body temperatue $\left(10^{\circ} \mathrm{C}\right)$ and active toads at high body temperatures $\left(30^{\circ} \mathrm{C}\right)$. Removal of the pericardial sac has no effect on Es. In addition, it is clear that al though thermally-induced changes in vio2 may be augmented by blood flow (Weathers, 1976), the increase in the $A-V O 2$ difference with activity found in this investigation shows that increased oxygen extraction plays a central role in producing the 
approximately 10-fold increase in vo2 (Hedrick, 1985) with enforced activity. 


\section{REFERENCES CITED}

Baustian, M. (1986). The Contribution of the Lymph Hearts in Compensation for Acute Hypovolemic stress in the Toad Bufo marinus. Unpubl. M. S. Thesis, Portland State University.

Becker, B., Rathscheck, W., Rachcheck, H., Muller, H. K. \& W. Schroeder (1970) - Sauerstoffdruck,

Sauerstoffverbrauch und Durchblutung in der Extremitatenmuskulatur des wachen Frosches. Pflugers Arch. 321:15-33.

Boutilier, R. G., Emilio, M. G. \& G. Shelton (1986). The Effects of Mechanical Work on Electrolyte and Water Distribution in Amphibian Skeletal Muscle. J. Exp. Biol. 120:333-350.

Carey, C. (1979). Aerobic and Anaerobic Energy Expenditure During Rest and Activity in Montane Bufo b. boreas and Rana pipiens. oecologia 39:213-228.

de Graff, A. R. (1957). Investigations into the Distribution of Blood in the Heart and Aortic Arches of Xenopus laevis (Daud.). J. Exp. Biol. 34:143-172.

Foxon, G. E. H. (1947). The Mode of Action of the Heart of the Frog. Proc. Zool. Soc. Lond. 116:56 5-574.

Foxon, G. E. H. (1951). A Radiographic study of the Passage of the Blood Through the Heart in the Frog and Toad. Proc. Zool. Soc. Lond, 121:529-538.

Foxon, G. E. H. (1955). Problems of the Double Circulation in Vertebrates. Biol. Rev. 30:196-228.

Foxon, G. E. H. \& E. W. Walls (1947) . The Radiographic Demonstration of the Mode of Action of the Heart of the Frog. J. Anat. Lond, 81:111-117.

Guyton, A. C. (1981). Textbook of Medical Physiology Saunders: Philadelphia.

Hall, F. G. (1966). Hemoglobin Functions in the Blood of Bufo marinus. J. Cell. Physiol. 68:69-74. 
Hedrick, M. S. (1985). Aspects of Cardiovascular Oxygen Transport in Vertebrates. Unpubl. M. S. Thesis, Portland State University.

Herman, C. A. (1977). Comparative Effects of Epinephrine and Norepinephrine on Plasma Glucose and Hematocrit Levels in the American Bullfrog (Rana catesbeiana). Gen. Comp. Endocrinole 32:321-329.

Hillman, S. S., Shoemaker, V. H., Putnam, R. \& P. C. Withers (1979). Reassessment of Aerobic Metabolism in Amphibians During Activity. J. Comp. Physiol. $129: 309-313$.

Hillman, S. S., Zygmunt, A. \& M. Baustian (1987a) . Transcapillary Fluid Forces During Dehydration in Two Amphibians. Physiol. Zool, 60:339-345.

Hillman, S. S., Withers, P. C., Palioca, W. B. \& J. A. Ruben (1987b). Cardiovascular Concequences of Hypercalcemia During Activity in Two Species of Amphibian. J. Exp. Zool. $242(3): 303-308$.

Johansen, K. (1963). Cardiovascular Dynamics in the Amphibian, Amphiuma tridactylum. Acta Physiol. Scand. Suppl. 60 (Suppl. 6I):1-82.

Johansen, K. \& A. S. F. Ditadi (1966). Double Circulation in the Giant Toad, Bufo paracnemis. Physiol. Zool. $39: 14 \emptyset-15 \emptyset$.

MbangRollo, D. \& R. de Roos (1983). Comparative Effects of Epinephrine, Norepinephrine, and Gentle Handling Stress on Plasma Lactate, Glucose, and Hematocrit Levels in the American Bullfrog (Rana catesbeiana). Gen, Comp. Endocrinol, 49:167-175.

McDonald, D. G., Boutilier, R. G. \& D. P. Toews (1980). The Effects of Enforced Activity on Ventilation, Circulation and Blood Acid-Base Balance in the Semi-Terrertrial Anuran, Bufo marinus. J. Exp. Biol. 84:273-287.

Meyers, R. S., Moalli, R., Jackson, D. C. \& R. W. Millard (1979). Microsphere Studies of Bullfrog Vascular Shunts During Diving and Breathing in Air. J. Exp, Z001. 208: 423-430.

Roth, J. J. (1973) - Vascular Supply to the Ventral Pelvic Region of Anurans as Related to Water Balance. J. Morph. 140:443-460. 
Tazawa, H., Mochizuki, M. \& J. Piiper (1979). Respiratory Gas Transport by the Incompletely Separated Double Circulation in the Bullfrog, Rana catesbeiana. Respir, Physiol. 36:77-95.

Tucker, V. (1967). Method for Oxygen Content and Dissociation Curves on Microliter Blood Samples. J. Appl. Physiol. 23:410-414.

Tufts, B. L., Mense, D. C. \& D. J. Randall (1987) . The Effects of Forced Activity on Circulating Catecholamines and $\mathrm{pH}$ and water Content of Erythrocytes in the Toad. J. Exp. Biel. 128:411-418.

Weathers, W. W. (1976). Influence of Temperature Acclimation on Oxygen Consumption, Haemodynamics and Oxygen Transport in Bullfrogs. Aust. J. Zoole 24:321-330.

Withers, P. C., Hillman, S. S., Simmons, L. A., \& A. C. zygmunt (1987). Cardiovascular Adjustments to Activity in Bufo marinus. Comp. Biochem. Physiol. In Press.

Zar, J. H. (1984) Biostatistical Analysis. Englewood Cliffs: Prentice-Hall.

Zygmunt, A. C. (1984). Effects of Dehydration on Hemoglobin Oxygen Affinity and Red Blood Cell Volume in Two Anurans. Unpubl. M. S. Thesis, Portland State University. 